\title{
BELAJAR DIENES
}

\author{
Oleh: Andi Ika Prasasti Abrar
}

Dosen Prodi Matematika STAIN Palopo

\begin{abstract}
Abstrak
Masalah yang sering kita dapati di lapangan adalah murid selalu merasa bosan untuk belajar matematika. Kenapa hal itu bisa terjadi ? karena adanya ketidakpahaman akan konsep matematika yang berkepanjangan yang dimulai dari tingkat awal. Masalah yang sering kita dapati di lapangan adalah murid selalu merasa bosan untuk belajar matematika. Kenapa hal itu bisa terjadi ? karena adanya ketidakpahaman akan konsep matematika yang berkepanjangan yang dimulai dari tingkat awal.
\end{abstract}

Kata Kunci: Belajar, Teori Dienes

\section{Pendahuluan}

Pendidikan matematika adalah bagian integral dari sistem pendidikan Nasional karena diajarkan pada semua jenjang pendidikan, hal ini menekankan bahwa Matematika mempunyai peranan penting dalam perkembangan Ilmu Pengetahuan dan Teknologi. Bahkan dalam kehidupan sehari-hari, prinsip dan konsep matematika selalu digunakan dalam memecahkan masalah.

Pengajaran matematika di tingkat dasar sebagai bagian dari sistem pendidikan nasional, menurut kurikulum 2006, bertujuan antara lain agar siswa memiliki kemampuan menggunakan penalaran pada pola dan sifat, melakukan manipulasi matematika dalam membuat generalisasi, menyusun bukti, atau menjelaskan gagasan dan pernyataan matematika. Hal ini mengisyaratkan bahwa pelajaran matematika pada dasarnya sangatlah abstrak, sehingga diperlukan metode atau strategi dalam menyampaikan materi matematika yang abstrak tersebut menjadi konkret, selanjutnya dari permasalahan yang konkret tesebut baru dialihkan kebentuk konsep-konsep matematika yang abstrak. Untuk mengawali penyampaian materi matematika yang abstrak melalui konkret itu dapat berpedoman pada teori belajar Dienes. Pada teori belajar Dienes, ditekankan pembentukan konsep-konsep melalui 
permainan yang mengarah pada pembentukkan konsep yang abstrak. Dengan demikian teori belajar Dienes sangatlah cocok diterapkan dalam pembelajaran matematika.

Masalah yang sering kita dapati di lapangan adalah murid selalu merasa bosan untuk belajar matematika. Kenapa hal itu bisa terjadi ? karena adanya ketidakpahaman akan konsep matematika yang berkepanjangan yang dimulai dari tingkat awal. Seterusnya, selain daripada masalah yang disebutkan, guru matematika juga dihadapkan pada masalah tidak adanya minat untuk mempelajari matematik dalam kalangan anak-anak di sekolah. Masalah tidak adanya minat ini seterusnya membawa kepada masalah yang kedua yaitu murid-murid gagal untuk menguasai kemahirankemahiran dasar dalam matematik. Masalah kurangnya minat siswa dalam belajar matematika, seharusnya mendorong para guru untuk menciptakan suasana belajar yang menyenangkan, dan kekreatifan guru dalam mendesain pembelajarannya. Sebagaimana yang dicontohkan dalam teori belajar Dienes

\section{Pembahasan}

Zoltan P. Dienes adalah seorang matematikawan yang memusatkan perhatiannya pada cara-cara pengajaran terhadap siswa-siswa. Dasar teorinya bertumpu pada Piaget, dan pengembangannya diorientasikan pada siswa-siswa, sedemikian rupa sehingga sistem yang dikembangkannya itu menarik bagi siswa yang mempelajarinya.

Teori belajar Dienes ini sangat terkait dengan teori belajar yang dikemukakan oleh Piaget, yaitu mengenai teori perkembangan intelektual. Jean Piaget berpendapat bahwa proses berpikir manusia sebagai suatu perkembangan yang bertahap dari berpikir intelektual konkret ke abstrak berurutan melalui empat periode. Urutan periode itu tetap bagi setiap orang, namun usia atau kronologis pada setiap orang yang memasuki setiap periode berpikir yang lebih tinggi berbeda-beda tergantung kepada masingmasing individu. 
a. Konsep Matematika

Dienes berpendapat bahwa pada dasarnya matematika dapat dianggap sebagai studi tentang struktur, memisah-misahkan hubungan-hubungan di antara struktur-struktur dan mengkategorikan hubungan-hubungan di antara struktur-struktur. Seperti halnya dengan Bruner, Dienes mengemukakan bahwa tiaptiap konsep atau prinsip dalam matematika yang disajikan dalam bentuk yang konkret akan dapat dipahami dengan baik. Ini mengandung arti bahwa jika benda-benda atau objek-objek dalam bentuk permainan akan sangat berperan bila dimanipulasi dengan baik dalam pengajaran matematika.

Dienes membedakan konsep matematika atas konsep murni, konsep notasi, dan konsep terapan. Konsep murni matematika merupakan ide-ide matematika mengenai klasifikasi bilangan dan relasi-relasi antar bilangan dan sama sekali tidak tergantung pada bagaimana bilangan tersebut disajikan. Konsep notasi matematika merupakan sifat-sifat bilangan yang merupakan akibat langsung dari cara bagaimana bilangan disajikan. Konsep terapan matematika merupakan penggunaan konsep murni dan konsep notasi matematika untuk pemecahan masalah matematika.

Dienes, memandang belajar sebagai suatu seni belajar kreatif. Dienes berpendapat bahwa setiap konsep matematika atau dalil, dapat dipahami secara baik, hanya jika disajikan kepada siswa secara konkret. Abstraksi dalam belajar matematika didasarkan pada intuisi dan pengalaman-pengalaman konkret. Untuk mempelajari matematika, siswa harus belajar untuk:

1. mengklasifikasikan struktur matematika dan relasi logikanya

2. mengabstraksi sifat-sifat bersama dari sejumlah struktur berbeda atau kejadian-kejadian dan mengklasifikasikan struktur atau kejadian-kejadian yang dimiliki bersama tersebut

3. menggeneralisaikan kelas-kelas struktur matematika yang telah dipelajari sebelumnya dengan memperbesarnya menjadi kelaskelas yang lebih luas, yang mempunyai sifat-sifat serupa yang terdapat dalam kelas-kelas yang lebih sempit. 
4. menggunkan abstarksi yang telah dipelajari sebelumnya untuk membentuk abstraksi yang lebih kompleks dan lebih tinggi tingkatannya.

\section{b. Konsep Dasar Teori Belajar Dienes}

Menurut Dienes, permainan matematika sangat penting sebab operasi matematika dalam permainan tersebut menunjukkan aturan secara konkret dan lebih membimbing dan menajamkan pengertian matematika pada anak didik. Dapat dikatakan bahwa objek-objek konkret dalam bentuk permainan mempunyai peranan sangat penting dalam pembelajaran matematika jika dimanipulasi dengan baik. Menurut Dienes, konsep-konsep matematika akan berhasil jika dipelajari dalam tahap-tahap tertentu. Dienes membagi tahaptahap belajar menjadi 6 tahap(Bell, dalam Ratumanan,2004), yaitu.

1. Permainan Bebas (Free Play). Permaianan bebas merupakan tahap belajar konsep yang aktivitasnya tidak berstruktur dan tidak diarahkan. Aktivitas ini memungkinkan anak mengadakan percobaan dan mengotak-atik (memanipulasi) bendabenda konkret dan abstrak dan unsur-unsur yang dipelajarinya itu. Dalam tahap permainan bebas anak-anak berhadapan dengan unsur-unsur dalam interaksinya dengan lingkungan belajarnya atau alam sekitar. Dalam tahap ini anak tidak hanya belajar membentuk struktur mental, namun juga belajar membentuk struktur sikap untuk mempersiapkan diri dalam pemahaman konsep. Penggunaan alat peraga matematika anak-anak dapat dihadapkan pada balokbalok logic yang dapat membantu anak-anak dalam mempelajari konsep-konseo abstrak. Dalam kegiatan belajar dengan menggunkan alat peraga ini anak-anak belajar mengenal warna, tebal tipisnya benda, yang merupakan ciri atau sifat dari benda yang dimanipulasinya itu.

2. Permainan yang Menggunakan Aturan ( Games ). Pada tahap ini, siswa mulai mengamati pola dan keteraturan yang terdapat pada konsep. Siswa memperhatikan bahwa ada aturan tertentu yang terdapat pada konsep (kejadian-kejadian). Aturanaturan tersebut adakalanya berlaku untuk suatu konsep, namun 
tidak berlaku untuk konsep lain. Segera setelah siswa menemukan aturan dan sifat yang menentukan kejadian, mereka siap melakukan permainan dan eksperimen dengan mengganti aturan dari guru menjadi aturan yang mereka buat sendiri.

3. Kesamaan Sifat (Searching for communalities). Dalam mencari kesamaan sifat anak-anak mulai diarahkan dalam kegiatan menentukan sifat-sifat kesamaan dalam permainan yang sedang diikuti. Untuk melatih anak-anak dalam mencari kesamaan sifatsifat ini, guru perlu mengarahkan mereka dengan mentranslasikan kesamaan struktur dan bentuk permainan yang satu ke bentuk permainan lainnya. Translasi ini tentu tidak boleh mengubah sifatsifat abstrak yang ada dalam permainan semula.

4. Penyajian / Representasi (Representations). Penyajian adalah tahap pengambilan kesamaan sifat dari beberapa situasi yang sejenis. Setelah siswa mengamati elemen-elemen bersama pada setiap contoh konsep, mereka perlu mengembangkan suatu penyajian tunggal dari konsep, yang mencakup semua elemen bersama yang terdapat pada setiap konsep. Penyajian tunggal ini dapat dilakukan dengan menggunakan diagram atau secara verbal. Penyajian konsep biasanya akan lebih abstrak daripada contohcontoh, dan akan membawa siswa lebih memahami struktur abstrak matematika.

5. Simbolisasi ( Symbolizations ). Pada tahap ini, siswa menghasilkan symbol-simbol matematika yang cocok untuk menyatakan konsep. Adalah hal yang sangat baik, jika siswa dapat menghasilkan symbol mereka sendiri dari setiap konsep.

6. Formalisasi ( Formalizations ). Formalisasi merupakan tahap belajar konsep yang terakhir. Dalam tahap ini siswa-siswa dituntut untuk mengurutkan sifat-sifat konsep dan kemudian merumuskan sifat-sifat baru konsep tersebut, sebagai contoh siswa yang telah mengenal dasar-dasar dalam struktur matematika seperti aksioma, harus mampu merumuskan teorema dalam arti membuktikan teorema tersebut.

Dienes menyatakan bahwa proses pemahaman (abstracton) berlangsung selama belajar. Untuk pengajaran konsep matematika 
yang lebih sulit perlu dikembangkan materi matematika secara konkret agar konsep matematika dapat dipahami dengan tepat. Dienes berpendapat bahwa materi harus dinyatakan dalam berbagai penyajian (multiple embodiment), sehingga anak-anak dapat bermain dengan bermacam-macam material yang dapat mengembangkan minat anak didik. Berbagai penyajian materi (multiple embodinent) dapat mempermudah proses pengklasifikasian abstraksi konsep.

Menurut Dienes, variasi sajian hendaknya tampak berbeda antara satu dan lainya sesuai dengan prinsip variabilitas perseptual (perseptual variability), sehingga anak didik dapat melihat struktur dari berbagai pandangan yang berbeda-beda dan memperkaya imajinasinya terhadap setiap konsep matematika yang disajikan. Dengan demikian, semakin banyak bentuk-bentuk berlainan yang diberikan dalam konsep tertentu, semakin jelas bagi anak dalam memahami konsep tersebut. Langkah selanjutnya, menurut Dienes, adalah memotivasi anak didik untuk mengabstraksikan pelajaran tanda material konkret dengan gambar yang sederhana, grafik, peta dan akhirnya memadukan simbol-simbol dengan konsep tersebut.

Langkah-langkah ini merupakan suatu cara untuk memberi kesempatan kepada anak didik ikut berpartisipasi dalam proses penemuan dan formalisasi melalui percobaan matematika. Anak didik pada masa kini bermain dengan simbol dan aturan dengan bentuk-bentuk konkret dan mereka memanipulasi untuk mengatur serta mengelompokkan aturan-aturan. Pada jaman ini anak didik menggunakan simbol-simbol sebagai objek manipulasi dan mengarah kepada struktur pemikiran-pemikiran matematika yang lebih tiggi. Anak harus mampu mengubah fase manipulasi konkret, agar pada suatu waktu simbol tetap terkait dengan pengalaman konkretnya.

\section{c. Prinsip-prinsip Belajar Matematika}

Teori Dienes mengariskan beberapa prinsip bagaimana anakanak mempelajari matematik yaitu: 
1. Prinsip Konstruktiviti: Pelajar haruslah memahami konsep sebelum memahaminya dengan analisa yang logik.

2. Prinsip Perubahan Perspeptual: Anak-anak diperkenalkan berbagai keadaan agar dapat memaksimakan konsep Matematik.

3. Prinsip Dinamik: Anak-anak mempelajari sesuatu melalui perkenalan dan eksperimen untuk membentuk satu konsep.

4. Prinsip variabilitas matematika: Konsep yang menyertakan variabel yang diajarkan melalui pengalaman dan menyertakan jumlah kemungkinan variabel yang paling besar.

Contoh Penerapan:

Berikut ini adalah salah satu contoh belajar konsep matematika dalam belajar menjumlah dan mengurang, dengan menerapkan keenam tahap belajar Dienes .

1. Permainan Bebas (Free Play) :

Dalam belajar menjumlahkan ataupun mengurang dengan permainan bebas, siswa diberikan kebebasan untuk bermain dan berinteraksi dengan lingkungan sekitar meraka. Misalnya anakanak dibagi dalam beberapa kelompok, kemudian setiap kelompok diberikan berbagai macam benda atau makanan, misalnya , bunga, permen atau balok-balok, dan sebagainya. Hal yang mungkin dilakukan anak-anak adalah bertanya kepada teman mereka, seperti ini:

a. ada berapa bunga yang warnanya merah?

b. saya ingin mengambil 2 permen, dan sisanya bisa kamu ambil!

2. Permainan dengan Menggunakan Aturan ( Games):

Games 1 : Bermain dalam Ruang Kesenian

Anak-anak dibawa dalam ruang kesenian. Aturannya, ruang kesenian tersebut hanya boleh diisi paling banyak sepuluh anak untuk latihan menari, dan anak-anak boleh keluar dan masuk kapan saja.Dari aturan tersebut akan menimbulkan banyak pertanyaan, dan anak- anak menjawab pertanyan, misalnya:

a. Jika dalam ruangan kesenian tersebut terdapat tujuh anak yang sedang latihan menari, berapa orang anak kah yang harus masuk untuk mencukupi? 
b. Jika anak-anak yang latihan menari semuanya sudah datang, dan ada dua orang anak meminta ijin keluar untuk minum, berapa anak yang berada di dalam ruang kesenian?

\section{Games 2 : Bermain mencari harta karun}

Anak-anak dibawa ke sebuah taman sekolah, dan bermain dengan mengikuti pola berikut: Caca dkk, sedang berburu harta karun dimulai dari pulau A dan pulau yang dituju adalah pulau E, meraka harus membawa BUNGA untuk sampai di sana. Di setiap pulau mereka boleh mengambil bunga, dan di setiap jembatan mereka boleh membuang bunga tapi untuk sampai di pulau E mereka harus membawa delapan bunga. Sekarang bantulah Caca dkk, untuk sampai di pulau tersebut dengan melewati pulau A, pulau B, pulau C, pulau F, pulau D kemudian kembali ke pulau B dan terakhir sampailah ke pulau E. Ingat di pulau A terdapat dua bunga, pulau $\mathrm{B}$ terdapat empat bunga, pulau $\mathrm{C}$ tidak ada bunga, pulau $\mathrm{D}$ terdapat tujuh bunga, dan pulau $\mathrm{F}$ ada satu bunga

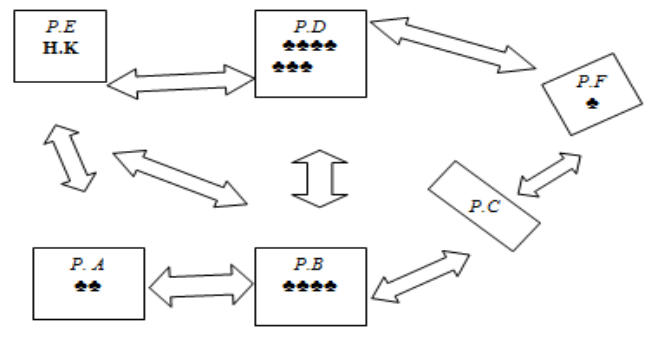

Dari aturan di atas akan memunculkan banyak pertanyaan, misalnya:

a. ada berapa bunga yang dibawa Caca, dkk untuk sampai di pulau $\mathrm{C}$, jika mereka tidak membuang bunga di jembatan?

b. Pada saat sampai di jembatan antara pulau F dan pulau D, Caca, dkk membuang dua bunga, ada berapa sisa bunga mereka?

3. Kesamaan Sifat (Searching for communalities)

Dari aktivitas pada games 1 dan games 2, anak-anak mungkin akan menemukan kesamaan sifat seperti ini: 
Games 1

Masuk dalam rungan

Keluar dari ruangan
Games 2

Mengambil bunga di pulau

Membuang bunga di jembatan

4. Penyajian / Representasi (Representations)

Dari games -games dan situasi yang telah diberikan diharapkan siswa dapat menyajikan secara abstrak apa yang mereka telah temukan. Misalnya:

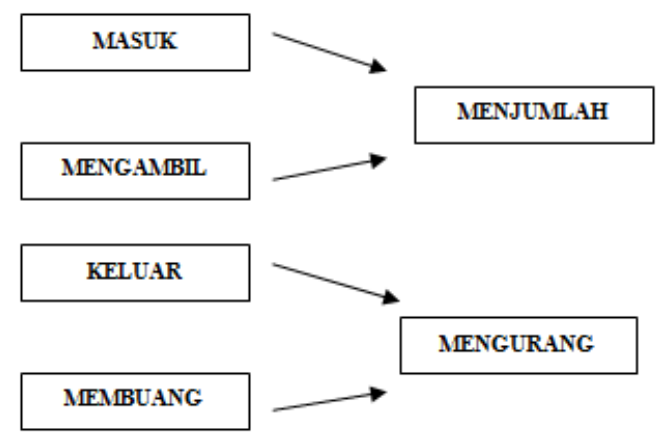

5. Simbolisasi ( Symbolizations)

Pada permainan dengan simbolisasi, anak-anak dapat menggunakan tanda tambah dan tanda kurang, ketika disebutkan kata-kata "masuk", "keluar", "mengambil", ataupun :membuang". Dan simbol-simbol angka ketika disebut "lima", "enam", dsb.

Sebagai contoh :

Dari 10 orang anak yang ada di ruang kesenian, dua orang keluar minum.

Ini dapat ditulis menjadi :

$10-2=8$

6. Formalisasi (Formalizations)

Tahap yang terakhir formalisasi. Pada tahap 6, dari gamesgames yang telah diberikan mungkin saja anak-anak memperoleh $2+3=5,3+2=5$, ataupun $0+3=3,3+0=3$. Dari sini, anak- anak akan bisa melihat sifat dari konsep 
tersebut, misalnya $2+3=3+2=5$, kemudian $0+3=3+0=3$, dan sebaginya.

\section{Penutup}

a. Simpulan

Berdasarkan pembahasan di atas dapat disimpulkan bahwa:

1. Konsep dasar teori belajar dienes meliputi 6 tahap yaitu: (1) bermain bebas, (2) bermain dengan aturan, (3) mencari kesamaan sifat, (4) penyajian, (5) simbolisasi, (6) formalisasi.

2. Pada teori belajar Dienes, ditekankan pembentukan konsepkonsep melalui permainan yang mengarah pada pembentukkan konsep yang abstrak.

b. Saran

Berdasarkan uraian dan simpulan mengenai Teori Belajar Dienes dapat disarankan kepada pengajar agar dalam mengajarkan matematika pada anak-anak (pada tingkat awal) diperlukan kreativitas dalam menciptakan suasana yang menyenangkan, misalnya dengan bermain dan berpedoman pada toeri belajar Dienes agar anak-anak dapat memahami konsep matematika tanpa harus menghadapi suasana kelas yang menegangkan.

\section{Daftar Pustaka}

Dienes, Z.P. 2000. Mathematical Games http://www.zoltandienes.com

Erman, Suherman, dkk. . Strategi Pembelajaran Matematika Kontemporer. Jurusan Pendidikan Matematika FMIPA UPI Mochamad Fathoni Arief. 2007. Belajar Sambil Bermain. http://fathoniarief.blogspot.com/2007/09/belajarmatematika-lewat-permainan.html

Ratumanan,T.G. 2004. Belajar dan Pembelajaran. Surabaya: Unesa University Press

Ratna, W.D., 1988. Teori-Teori Belajar, Pascasarja, Bandung. Tadjab, 1992. Ilmu Jiwa Pendidikan, Karya Abditama, Surabaya.

Tim MKPBM, 2001. Strategi Pembelajaran Matematika Kontemporer, JICA-UPI, Bandung. 